\title{
Perancangan Aplikasi Pengenalan Pendidikan Islam Berbasis Android Untuk Pendidikan Anak Usia Dini
}

\author{
Desmira $^{1}$, Rizal Fauzi ${ }^{2}$ \\ Program Studi Teknik Informatika - STIMIK NUSAMANDIRI \\ 1desmira.dma@bsi.ac.id \\ ${ }^{2}$ rizalfauzi088@gmail.com
}

\begin{abstract}
Abstrak - Pendidikan islam adalah pendidikan yang wajib diketahui terutama bagi anak usia dini. Waktu masih menjadi kendala bagi para orang tua dalam mengenalkan kepada anak tentang pendidikan islam. Kini anak-anak sudah tidak asing dengan smartphone. Smartphone memiliki sistem operasi android. Aplikasi android dapat menjadi media pembelajaran interaktif yang disukai oleh anak -anak karena konten tidak hanya berbentuk teks tertulis namun juga bisa berupa suara dan gambar sehingga tidak membuat anak-anak jenuh dalam belajar. Oleh karena itu, penulis membuat aplikasi pengenalan pendidikan islam berbasis android untuk pendidikan anak usia dini. Proses pembuatan aplikasi ini menggunakan eclipse sebagai editing program dan aplikasi adobe photoshop CS6 sebagai editingdesign dan adobe audition sebagai editing suara. Aplikasi ini dibuat sebagai media pengenal yang membantu anak dalam mengenal pendidikan islam pada usia dini, terutama dalam pengenalan huruf hijaiyah, do'a harian Anak, nama malaikat dan nama nabi. Aplikasi ini bersifat offline.
\end{abstract}

Kata Kunci : Pendidikan Islam, Smartphone, Aplikasi, Android

\section{PENDAHULUAN}

Smartphone adalah salah satu teknologi informasi yang terus berkembang mengikuti perkembangan zaman. Smartphone kini banyak digunakan oleh orang dewasa, remaja, dan bahkan anak-anak kini sudah memiliki smartphone. Smartphone bekerja menggunakan perangkat lunak sistem operasi. Salah satu perangkat lunak yang digunakan oleh smartphone ialah android. Android sebagai sistem operasi berbasis linux. Android memiliki tujuan utama untuk memajukan inovasi piranti telepon bergerak agar pengguna mampu mengeksplorasi kemampuan dan menambah pengalaman lebih dibandingkan dengan platform mobile lainnya. Android memiliki banyak aplikasi yang bisa dibuat seperti aplikasi pemasaran suatu jasa,aplikasi pembelajaran, dan masih banyak lagi. Aplikasi-aplikasi ini bisa bersifat open source maupun berbayar. Hingga saat ini android terus berkembang, baik secara sistem maupun aplikasinya.

Setelah penulis melakukan observasi, penulis menemukan masalah bahwa anak lebih senang menghabiskan waktu dengan smartphone dibandingkan dengan mengaji. Sehingga mempengaruhi pengetahuan tentang agama islam sang anak.
Begitu juga para orang tua, masih banyak dari mereka yang sibuk dengan urusannya sehingga kurangnya perhatian dari orang tua terhadap anak dalam pendidikan islam.

Mengingat masih banyak anak yang belum mengerti tentang dasar-dasar islam seperti nama malaikat dan tugasnya. Maka penulis merancang aplikasi pengenalan pendidikan islam, karena diharapkan aplikasi ini dapat membantu anakdalam mengenal tentang pendidikan islam dengan smartphone kesayangannya.

\section{METODOLOGI PENELITIAN}

Untuk mengimplementasikan aplikasi yang akan dibuat oleh penulis memerlukan analisa untuk kebutuhan dalam peranacangan diantaranya:

a. Planning

Mempersiapkan Hardware dan Software yang akan digunakan untuk perancangan aplikasi sampai rencan pembuatan program berbasis android.

b. Analisis

Menganalisis permasalahn serta kebutuhan pengguna tentang perancangan aplikasi androiddan kelemahan program aplikasi tehnologi yang akan digunakan.

c. Desain

Software Architecture yang digunakan penulis untuk aplikasi ini berdasarkan OOP (object Oriented Programming), dimana OOP ini adalah inti dari pemrograman java sehingga adanya class-class dan atribut-atribut yang akandipakai didalam aplikasi. Sedangkan untuk user interface penulis membuat didalam aplikasi ini terdapat tombol -tombol yang digunakan untuk memilih.

d. Testing

Pengujian yang dilakukan secara white box, menguji setiap dari statementcoding dan alur yang penulis buat, sehingga mendapatkan hasil yang sesuai. Sedangkan pengujian yang dilakukan secara black box, menggunakan tabel-tabel validasi yang akan dicocokkan dengan aplikasi sehingga mendapatkan hasil yang valid.

e. Implementasi

Pengujian di AVD (Android Virtual Device) tidak ada kesalahan maka aplikasi diinstal kedalam Mobile dengan operasi sistem android.

f. Support 
Adapun kebutuhan system minimum requiments,yang dibutuhkan untuk menjalankan aplikasi android ini adalah sebagai berikut:

Spesifikasi minimum software:Android Jelly

Bean.

Spesifikasi minimum hardware: RAM (Random Access Memory) 512 MB.

\section{DASAR TEORI}

\subsection{Konsep Dasar Program}

Konsep dasar program yang digunakan dalam pembuatan aplikasi android adalah:

a. Java

Java adalah bahasa pemrograman yang multi platform dan multi device. Java dapat dijalankan dalam beberapa platform komputer dan sistem operasi yang berbeda. Aplikasi dengan berbasis java ini dikompulasikan ke dalam pseudecode dan bisa dijalankan dengan JVM (Java VirtualMachine). Fungsionalitas dari java ini dapat berjalan dengan platform sistem operasi yang berbeda karena sifatnya yang umum dan non-spesific.Java juga merupakan bahasa pemrograman berorientasi OOP (Object Oriented Programming). Java memiliki library yang lengkap. Library disini adalah sebuah kumpulan dari program yang disertakan dalam java. Hal ini akan memudahkan pemrograman menjadi lebih mudah.

b. Android

Android adalah sebuah sistem operasi untuk perangkat mobile berbasis linux yang mencakup sistem operasi, middleware dan aplikasi[8]. Android memiliki banyak versi mulai dari pertama kali dibuat hingga yang digunakan sampai saat ini. JDK (Java Development Kit) adalah program development environment untuk menulis java applets dan aplikasi. JDK terdiri dari runtimeenvironment yang ada diatas layer sistem operasi serta tools dan program yang memerlukan compile, debug, dan run applets dan aplikasi yang ditulis menggunakan bahasa pemrograman Java. Java Develovment Kit digunakan untuk plugin bahasa pemrograman java.

\subsection{Metode Algoritma}

Sebelum membahas mengenai metode algoritma yang digunakan penulis, berikut ini adalah pengertian dari metode dan algoritma:

\section{Metode}

Metode atau method secara harifah diartikan sebagai cara atau jalan yang ditempuh. Secara etimologis, istilah ini berasal dari kata "met" dan "hodes" yang berarti melalui. Selain itu, metode atau metodik berasal dari bahasa greeka, "metha" yang berarti melalui atau melewati, dan "hodos" yang berarti jalan atau cara. Jadi dapat disimpulkan bahwa metode adalah prosedur atau cara yang ditempuh oleh seseorang untuk mencapai tujuan tertentu.

2. Algoritma
Algoritma adalah suatu metode khusus yang tepat dan terdiri dari serangkaian langkah yang terstruktur dan ditulliskan secara matematis, yang akan dikerjakan untuk menyelesaikan suatu masalah. Algoritma bisa disajikan dalam dua bentuk, yakni dalam bentuk tulisan dan gambar. Bila disajikan dalam bentuk tulisan harus menggunakan bahasa yang dapat dimengerti, terutama dalam mengajikan langkah-langkah algoritma. Penyajian dalam bentuk tulisan bisa dilakukan dengan pseudecode yang berarti menggunakan kode program. Sedangkan, penyajian algoritma dalam bentuk gambar dalam bentuk gambar sering disebut flow chart.

\subsection{Pengujian Software}

Pengujian adalah satu set aktifitas yang direncanakan dan sistematis untuk menguji atau mengevaluasi kebenaran yang diinginkan[2].

Didalam pengujian software terdapat beberapa metode diantaranya adalah:

1. Metode Pengujian Black Box

Black-Box Testing yaitu menguji perangkat lunak dari segi fungsional tanpa menguji desain dan kode program[2].

2. Metode Pengujian White Box white-Box Testing yaitu menguji perangkat lunak dari segi desain dan kode program apakah mampu menghasilkan fungsi-fungsi, masukkan, dan keluaran yang sesuai dengan spesifikasi kebutuhan[2].

\subsection{Peralatan Pendukung}

Membuat suatu aplikasi android diperlukan berbagai macam pendukung yang dapat membantu terbentuknya suatu aplikasi mulai dari logika hingga konsep pemrogramannya.

1) OOP

Sebuah paradigma pemograman yang berdasarkan pada konsep objek yang terdiri atas struktur data yang berupa variabel atau kode yang disebut dengan prosedur atau method. Didalam OOP, program komputer dibuat sebagai objek yang saling berinteraksi antara satu sama lain. Kebanyakan dari OOP berdasarkan class dimana objek dibuat dari class yang pada akhirnya juga menentukan tipe dari objek tersebut. Bahasa pemograman terkenal yang berdasarkan konsep OOP adalah Java, $\mathrm{C}++$, Phyton, C\#, Ruby, Objective-C, Perl, PHP, Delphi dan Smalltalk.

2) UML (Unified Modelling Languange)

UML adalah salah satu standar bahasa yang banyak digunakan di dunia industri untuk mendefinisikan requirement, membuat analisis dan desain, serta menggambarkan arsitektur dalam pemrograman berorientasi objek[9]. Dengan kata lain UML berarti bahasa pemodelan standar dan merupakan alat komunikasi yang konsisten dalam mensuport para pengembang saat ini[10].

Dari kedua pendapat tersebut, dapat disimpulkan bahwa UML adalah bahasa pemodelan sistem yang digunakan sebagai alat komunikasi antara pengembang 
dengan pengguna atau antar pengembang itu sendiri untuk pemrograman berorientasi objek (Object Oriented Programming).

\section{TEKNIK PENGUMPULAN DATA}

Dalam membangun aplikasi ini terlebih dahulu dilakukan pengumpulan data yaitu :

1. Observasi

Penulis melakukan pengamatan secara langsung pada para pemakai tehnologi komputer atau tehnologi selular.

2. Studi Pustaka

Merupakan jenis penelitian yang dilakukan dengan mengumpulkan data yang berhubungan dengan topik permasalahan dari judul yang penulis buat. Hal ini dilakukan dengan cara membaca buku-buku, makalah, maupun artikel-artikel untuk mendapatkan landasan teoritis yang mencukupi.

\section{ANALISA KEBUTUHAN}

Tahap analisa kebutuhan mencakupi hardware, software dan aplikasi yang digunakan sebagai berikut:

a. Kebutuhan Hardware

Komputer yang digunakan penulis dalam pembuatan aplikasi ini memiliki spesifikasi sebagai berikut:

Tabel 1:

Spesifikasi laptop

\begin{tabular}{|c|c|}
\hline Tipe & A455L \\
\hline & Intel Core i3-4030U, \\
Proccesor & DDR3L 2 GB \\
\hline RAM & $500 \mathrm{~GB}$ \\
\hline Harddisk & Nvidia GeForce GT \\
\hline & $820 \mathrm{M} 3 \mathrm{~GB}$ \\
\hline Grafik & \\
\hline
\end{tabular}

Dalam pembuatan aplikasi androidminimal harus menggunakan ProcessorDual Core karena akan berpengaruh terhadap pembuatan virtualandroidyang akan digunakan.

Perangkat gadget yang digunakan penulis mempunyai spesifikasi sebagai berikut:

Tabel 2:

SpesifikasiGadget

\begin{tabular}{|c|c|}
\hline Tipe & Andromax C2 \\
\hline Proccesor & $\begin{array}{c}\text { Snapdragon DualCore 1.2 } \\
\text { GHz Cortex A7 }\end{array}$ \\
\hline RAM & $512 \mathrm{MB}$ \\
\hline Internal Memory & $8 \mathrm{~GB}$ \\
\hline Layar & $\begin{array}{c}4.0 \text { 'W GA (480 x 800 } \\
\text { pixel) }\end{array}$ \\
\hline Sistem Operasi & 4.3Jelly Bean \\
\hline
\end{tabular}

Pada pembangunan aplikasi ini dibutuhkan spesifikasi minimal hardware sebagai berikut :
Kebutuhan hardware

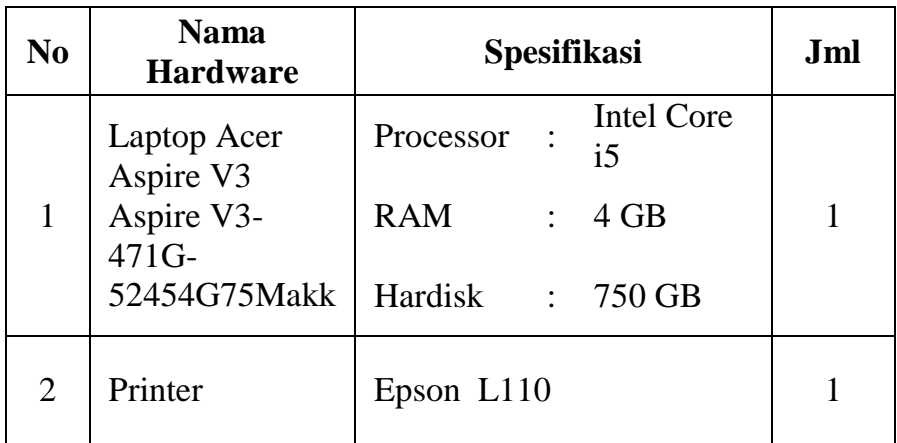

b. Kebutuhan Software

Software yang digunakan untuk pembangunan aplikasi sebagai berikut :

Tabel 4:

Kebutuhan software

\begin{tabular}{|c|c|c|c|}
\hline No & Kebutuhan & Keterangan & Fungsi \\
\hline 1 & $\begin{array}{l}\text { Sistem } \\
\text { Operasi }\end{array}$ & $\begin{array}{l}\text { Microsoft } \\
\text { Windows } 8.1 \\
\text { Pro }\end{array}$ & $\begin{array}{c}\text { Sebagai Sistem } \\
\text { Operasi yang } \\
\text { dipakai untuk } \\
\text { menjalankan } \\
\text { Software } \\
\end{array}$ \\
\hline \multirow{4}{*}{2} & \multirow{4}{*}{ Aplikasi } & $\begin{array}{c}\text { JDK (Java } \\
\text { Development } \\
\text { Kit) }\end{array}$ & Develop program \\
\hline & & Eclipse Juno & $\begin{array}{c}\text { Tampilan } \\
\text { interface program }\end{array}$ \\
\hline & & $\begin{array}{l}\text { ADT(Android } \\
\text { Development } \\
\text { Tools)plugin }\end{array}$ & Android plugin \\
\hline & & $\begin{array}{l}\text { Android SDK } \\
\text { (Software } \\
\text { Development } \\
\text { Kit) }\end{array}$ & $\begin{array}{c}\text { Emulator Android } \\
\text { di PC }\end{array}$ \\
\hline
\end{tabular}

\section{ANALISA PENGGUNA}

Untuk memasang aplikasi ini digunakan perangkat atau handphone smartphone berbasis android minimal android4.2 (Jellybean) -API Level 17 RAM 512MB resolution WVGA 4.0".

Testing dilakukan dengan melakukan beberapa tahap sebagai berikut :

a. White Box

\section{Tabel 3:}




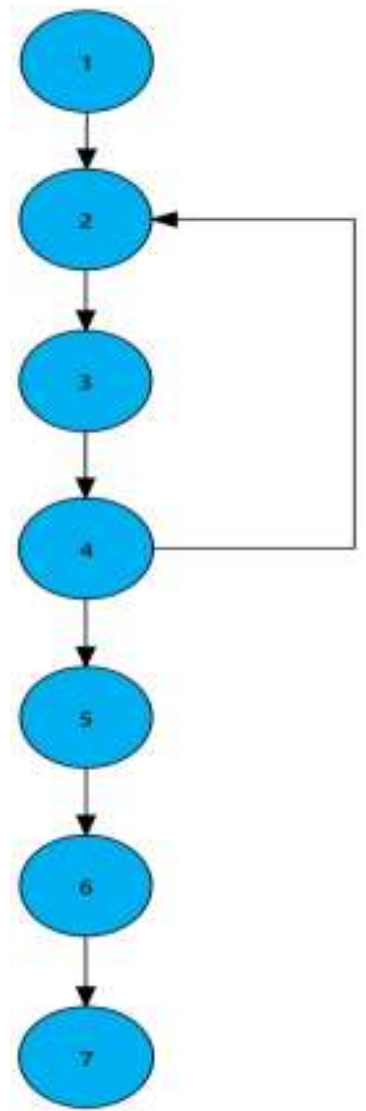

Gambar 1:

b.Black Box

Skema Diagram Alir Quiz

Pengujian selanjutnya dilakukan untuk memastikan bahwa suatu event atau input menjelaskan proses yang tepat dan menghasilkan output yang sesuai dengan rancangan yang telah dibuat.

Tabel 5:

Tabel Pengujian Black Box

\begin{tabular}{|c|c|c|c|}
\hline Input & Process & Output & Validasi \\
\hline Image & Menampilkan & Tampil & \\
Button & Layout Huruf & $\begin{array}{c}\text { Layout } \\
\text { Huruf }\end{array}$ & Sukses \\
Huruf & Hijaiyah & Hijaiyah & \\
Hijaiyah & & Tampil & \\
\hline Image & & Layout & \\
Button & Menampilkan & \multirow{2}{*}{ Sukses } \\
Doa & Layout daftar & Daftar & \\
harian & doa harian & doa & \\
anak & & harian & \\
Image & Menampilkan & Tampil & \\
Button & Layout Nama & layout & \multirow{2}{*}{ Sukses } \\
Nama & Malaikat & Malaikat & \\
Malaikat & Tampil & \\
Image & Menampilkan & Layout & Sukses \\
Button & LayoutNama & Nama & \\
Nama & Nabi & Nabi & \\
Nabi & & Tampil & Sukses \\
\hline Image & Menampilkan & \multicolumn{2}{|c}{} \\
\hline
\end{tabular}

\begin{tabular}{|c|c|c|l|}
\hline $\begin{array}{c}\text { Button } \\
\text { Lagu } \\
\text { Religi } \\
\text { Anak }\end{array}$ & $\begin{array}{c}\text { Layout Menu } \\
\text { Lagu Religi }\end{array}$ & $\begin{array}{c}\text { Layout } \\
\text { Menu } \\
\text { Lagu }\end{array}$ & \\
& & $\begin{array}{c}\text { Religi } \\
\text { Anak }\end{array}$ & \\
\hline Image & Menampilkan & Tampil & \\
Button & Layout & Sukses \\
Quiz & Layout Soal & Soal & \\
\hline Image & Menampilkan & Tampil & \\
Button & Layout & Layout & Sukses \\
Bantuan & Bantuan & Bantuan & \\
\hline Button & Menampilkan & Tampil & \\
Tentang & Layout & Layout & Sukses \\
& Tentang & Tentang & \\
\hline
\end{tabular}

VII. ANALISA DATA

Data yang menunjang mengenai pembuatan aplikasi ini dikumpulkan mulai dari survei dan mengumpulkan data di kebutuhan masyarakat tentang ilmu islam yang disesuaikan dengan perkembangan teknologi saat ini, dari internet dan dari buku- buku yang telah dipelajari. Lalu data tersebut diolah dan diproses sehingga menjadi sebuah aplikasi informasi yang di buat menggunakan IDE Eclipse, dengan plugin Android Development Tool dan Android SDK. Namun terlebih dahulu menginstal Java Development Kit agar Eclipse bisa berjalan dengan baik.

\section{PERANCANGAN}

Rekayasa perangkat lunak merupakan pembangunan menggunakan prinsip dan konsep rekayasa dengan tujuan menghasilkan perngakat lunak yang bernilai ekonomi yang dipercaya dan bekerja secara efisien menggunakan mesin. Perangkat lunak banyak dibuat dan pada akhirnya sering tidak digunakan karena masalah-masalah nonteknis

1. Use Case Diagram Aplikasi Pengenalan Pendidikan Islam

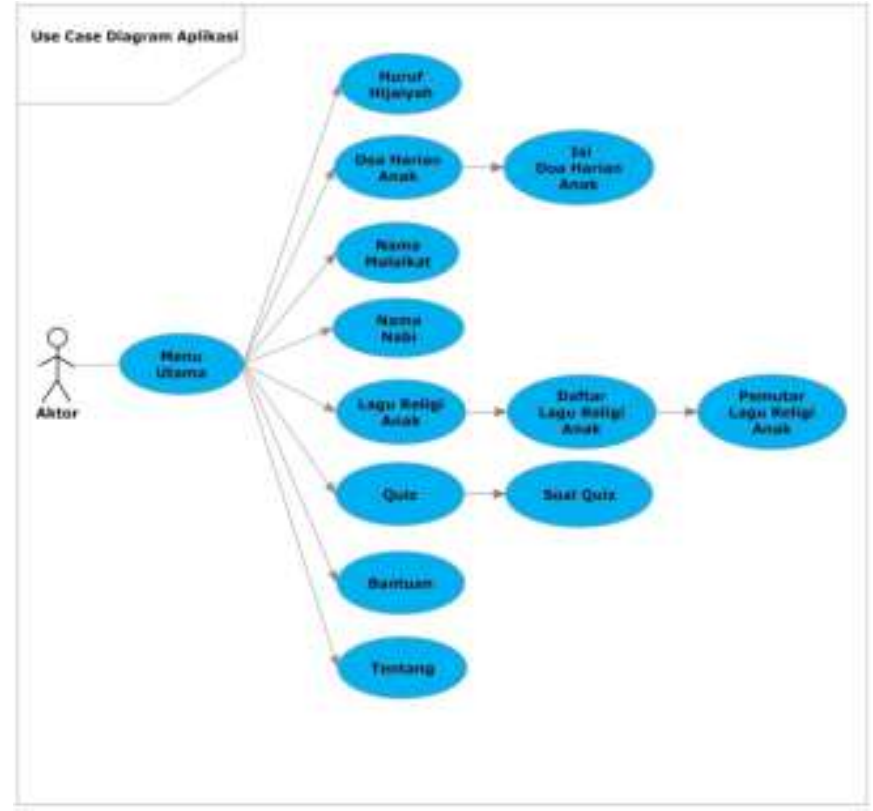




\section{Gambar 2: \\ Use Case Diagram Aplikasi Pengenalan \\ Pendidikan Islam}

Pada use case diagram ini menjelaskan dimana aktor merupakan anak usia dini yang menggunakan aplikasi pengenalan pendidikan Islam ini. Di dalam aplikasi ini terdapat sembilan menu yaitu huruf hijaiyah, doa harian anak, nama malaikat, nama nabi, lagu religi anak, quiz, bantuan dan tentang. Ketika sang anak memilih menu huruf hijaiyah maka akan tampil halaman huruf hijaiyah yang dapat bersuara ketika sang anak menekan huruf hijaiyah tersebut. Ketika sang anak memilih menu doa harian anak maka yang akan tampil berikutnya adalah halaman daftar doa harian. Kemudian halaman nama malaikat dan nama nabi akan tampil jika sang anak memilih menu nama malaikat dan nama nabi. Jika sang anak memilih menu lagu religi anak, yang akan tampil adalah daftar lagu religi anak. Padamenu daftar lagu religi anak, sang anak bisa memilih dan memutarnya pada halaman pemutar lagu religi anak. Ketika sang anak memilih menu quiz maka sang anak akan dihadapkan dengan sepuluh soal tentang materi yang ada diaplikasi ini. Halaman cara penggunaan aplikasi akan tampil ketika sang anak memilih menu bantuan. Jika sang anak memilih menu tentang, maka akan tampil tentang penulis.

\section{HASIL DAN PEMBAHASAN}

Berikut fasilitas-fasilitas yang disediakan pada aplikasi seperti terlihat pada gambar tampilan di bawah ini :

1) Splash Screen

Pada awal tampilan akan muncul gambar dibawah ini :

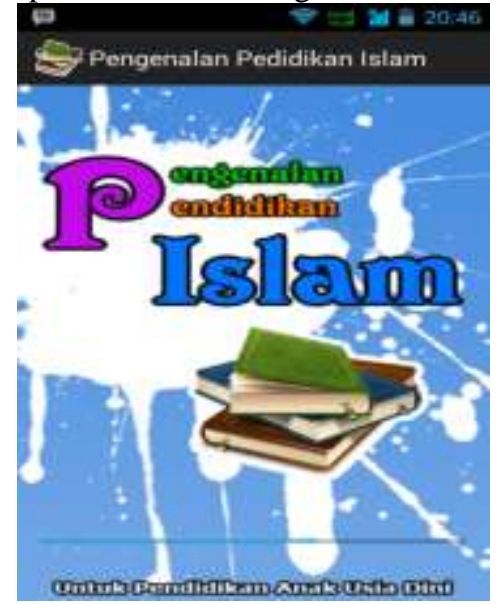

Gambar 3:

Tampilan Splash Screen

2) Menu Utama

Menu utama adalah bagian dari aplikasi yang muncul dengan tampilan di bawah ini :

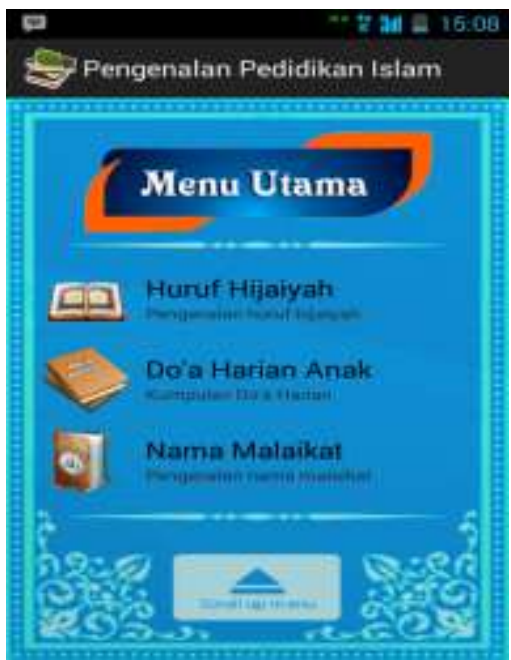

Gambar 4:

Tampilan Menu Utama

3) Tampilan Menu Huruf Hijaiyah

Ketika User mengklik sub menu huruf hijaiyah maka akan muncul tampilan berikut :

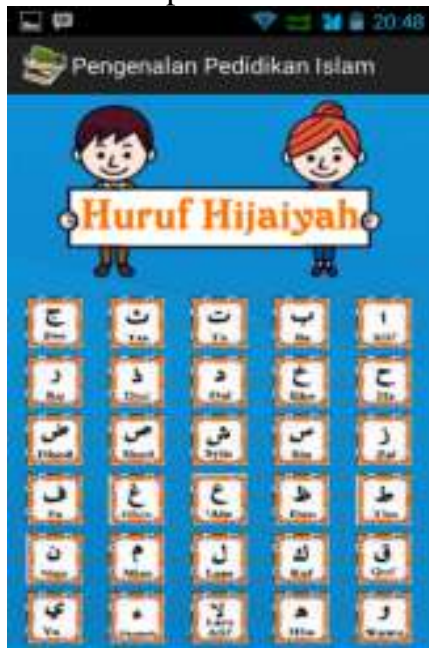

Gambar 5:

Menu Huruf Hijaiyah

4) Tampilan Menu Doa Harian Anak

Pada sub menu Doa Harian Anak akan memunculkan dengan tampilan berikut : 


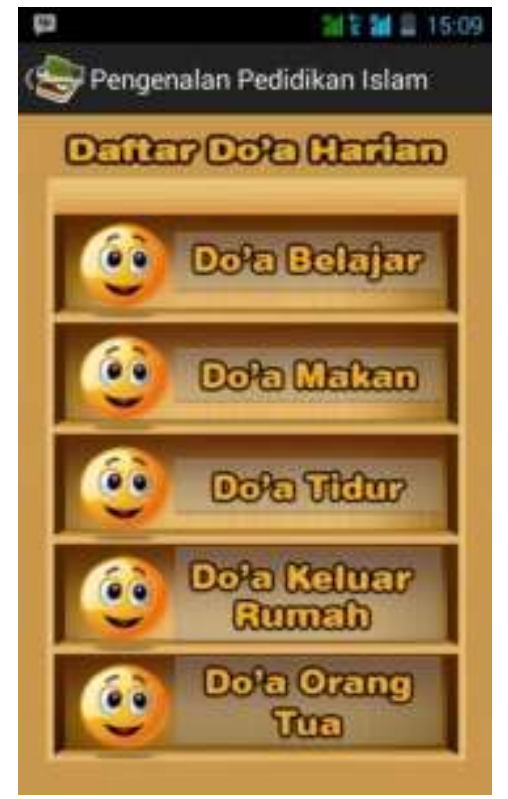

Gambar 6:

Doa Harian Anak

5) Tampilan Do'a Belajar

Tampilan Do'a Belajar sebagai berikut :

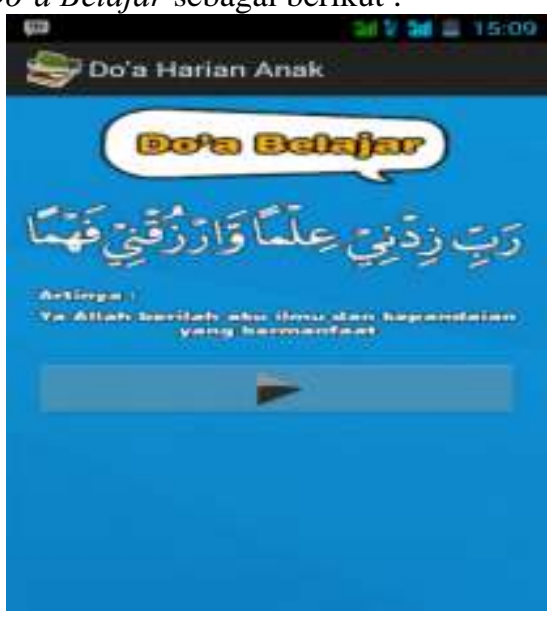

Gambar 7:

Tampilan Do'a Belajar

6) Tampilan Menu Nama Malaikat

Pada sub menu tampilan doa malaikat akan memunculkan sub menu lainnya seperti berikut ini :

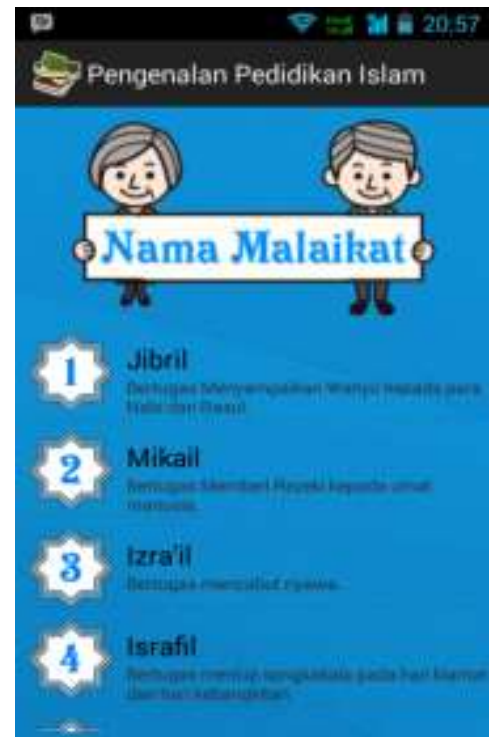

Gambar 8:

Tampilan nama malaikat

7) Tampilan Menu Nama Nabi

Pada sub menu ini terdapat informasi mengenai nama nabi seperti dibawah ini :

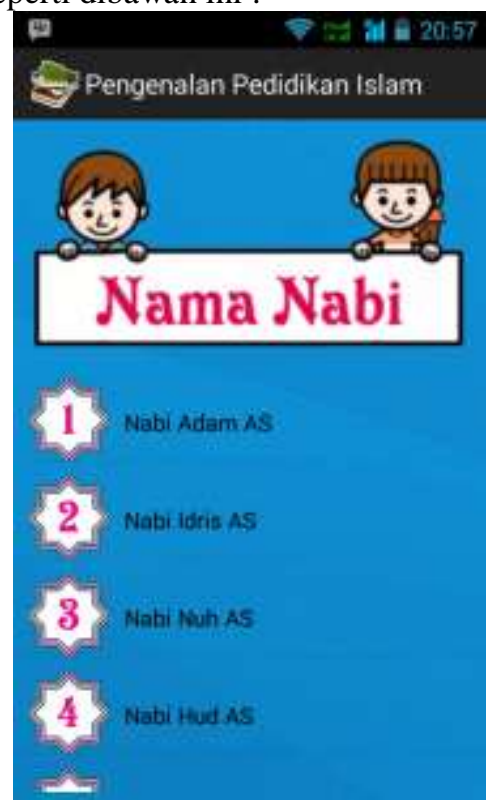

Gambar 9:

Tampilan nama malaikat

8) Tampilan Menu Lagu Religi Anak

Pada sub menu ini terdapat informasi mengenai lagu religi anak berikut penjelasannya seperti di bawah ini 


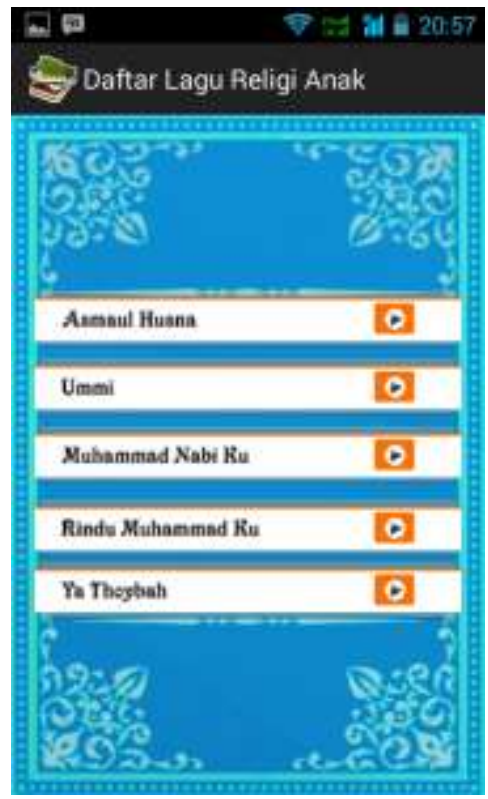

Gambar 10:

Tampilan menu Daftar lagu religi anak

9) Tampilan Soal Quiz

Tampilan Soal quis terdapat pada sub menu ini :

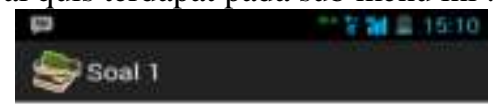

Manakah hurut ro?

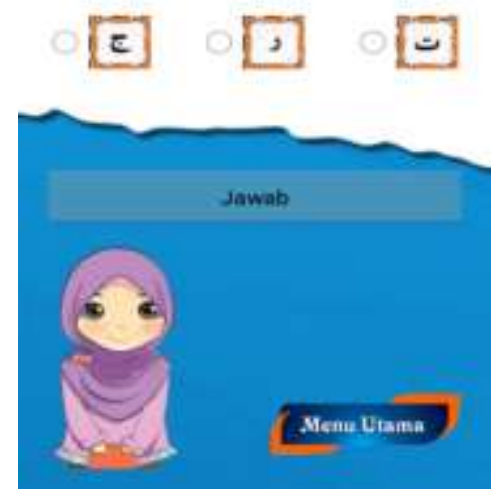

Gambar 11:

Tampilan Soal quis

10) Tampilan Menu Bantuan

Berikut adalah tampilan menu bantuan :

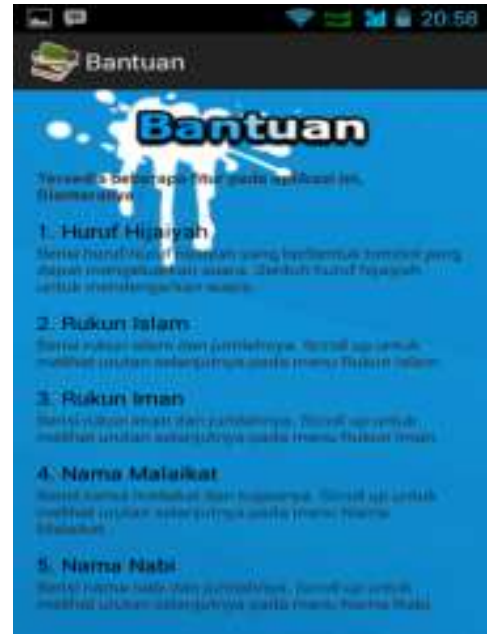

Gambar 12:

Tampilan menu bantuan

11) Tampilan Menu Tentang

Pada sub menu ini terdapat informasi mengenai menu tentang seperti dibawah ini :

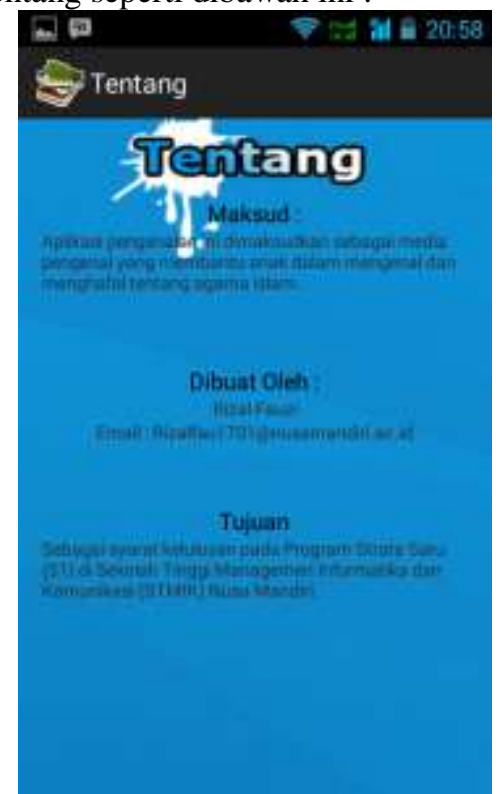

Gambar 13:

Tampilan menu tentang

\section{SIMPULAN}

Sesuai dengan uraian dan penjelasan serta pembahasan keseluruhan materi pada bab-bab sebelumnya dan dalam mengakhiri pembahasan "Aplikasi Pengenalan Pendidikan Islam Berbasis Android UntukPendidikanAnakUsiaDini" maka dapat diambil beberapa kesimpulan sebagai berikut:

1. Dengan adanya aplikasi ini anak - anak menjadi lebih mudah dalam mempelajari huruf hijaiyah, doa harian anak, nama malaikat, dan nama nabi.

2. Aplikasi ini berjalan di device android dengan platformminimal 4.2 (Jelly Bean).

3. Aplikasi ini dilengkapi lagu religi anak untuk menghibur anak dalam belajar mengenal pendidikan islam. 
4. Pada aplikasi pengenalan pendidikan islam ini terdapat quiz, dimana anak bisa mencoba kemampuannya dalam memahami apa yang dia pelajari pada aplikasi ini.

\section{DAFTAR PUSTAKA}

1. Aprilianti, dkk. (2013). Aplikasi Mobile Game Edukasi Matematika Berbasis Android Application Of Education Mobile Games For Math Based On Android. September 2013: 2338-6304.

2. M. Shalahuddin dan Rossa A.S. (2014). Rekayasa Perangkat Lunak Terstruktur dan Berorientasi Objek. Bandung: Informatika.

3. Muyassar. (2015). Apa Itu OOP (Object Orientation Programming). Diambil dari:

http://www.updateilmu.com/apa-itu-oop-object-orientedprogramming/. (14 Januari 2015)

4. Nugroho, Suryo. (2014). Perancangan Aplikasi Pembelajaran Fiqih Menggunakan Metode Computer Based Instruction Berbasis Mobile Learning

5. Purwanti, Ika.(2013).Perancangan Aplikasi Pembelajaran Huruf Hijaiyah Berplatform
6. Android Untuk Madrasah Baca Tulis Al Quran Al-Fattah Desa Widodaren Kabupaten

7. Ngawi, Seminar Riset Unggulan Nasional Informatika dan Komputer FTI UNSA 2013, Vol 2 No 1 - Maret 2013 ISSN: 2302-1136 - seruniid.unsa.ac.id, pp.123130 .

8. Safaat, Nazruddin. (2012). "Pemrograman Aplikasi Mobile Smartphone dan Tablet PC Berbasis Android". Bandung : Informatika

9. Shalahuddin, Muhammad \& Rosa Ariani S, 2011. Modul Pembelajaran Rekayasa Perangkat Lunak (Terstruktur dan Berorientasi Objek). Bandung: Modula.

10. Widodo, Prabowo Pudji \& Herlawati, 2011. Menggunakan UML. Bandung: Informatika. 